\title{
Identifying Character of Lempu in Local History Lesson of South Sulawesi
}

\author{
Bahri \\ Universitas Negeri Makasar \\ Makassar, South Sulawesi \\ bahrisejarah@gmail.com \\ Amiruddin \\ Universitas Negeri Makasar \\ Makassar, South Sulawesi \\ amiruddin@gmail.com
}

\author{
Andi Dewi Riang Tati \\ Universitas Negeri Makasar \\ Makassar, South Sulawesi \\ aidilqifa@gmail.com
}

\begin{abstract}
The diversity of the character value both in cultural traditions, religious teachings, and the leadership teaching can be integrated into the teaching process. In the local history of South Sulawesi, various grades of characters are illustrated in various paseng (messages) and in lontarak by to acca (the scholars) that can be a reference in creating progressors character generation. One of the intended values is lempu that can be found in South Sulawesi especially in local historical events. In philosophy, there are two things that are used by Bugis-Makassar people to fence themselves, they are paccing and lempu (clean and honest). The Various grades of lempu also can be found in paseng that proposed by Kajao Laliddong, Arung Bila, and To Ciung. The Paseng illustrated in the dialogue between to acca and the king, the treaty between the kingdoms that contains about how the importance of honesty value for a king as a leader. In the various lontarak and paseng, also found the impact caused by the values of honesty that are ignored by the king in his administration. The value of Lempu is inherited by its predecessors in the mosaic of local history which is retained in the South Sulawesi government and indigenous communities until now. The indigenous communities in South Sulawesi can be found in some areas such as Ammatoa in Bulukumba, Tolotang in Sidrap and Karampuang in Sinjai.
\end{abstract}

Keywords-lempu character; teaching local history

\section{INTRODUCTION}

Various cultures at communities who occupy South Sulawesi territory is assets had not been exposed in the educational domain. Those had been presented in some sources either oral tradition or oral history natures. Oral tradition forming paseng, along or passing collected some character values of South Sulawesi in the past. As well as siri' na pacce which has abstract characteristic also its inspiration for the following generation in tracing current life way and for the future. Oral history as had been presented either in lontarak or another written resource to be life guidance by following so complex era progress rhythm.

The character value of lempu (honest) and other character values as a reference for communities of Bugis
Makassar in some daily activities. Character values of lempu either implied in paseng or even in lontara for the educational domain as a reference for all educational levels including college. In college especially, integration of character value in study subject is still very absurd. Study subject based on study program or department completed with study subject in general, it remains as a commodity for students who hunger character values as provision for sailing through the dedication field in the midst of communities. The presence of interorganization or campus extracurricular solely, it is the only facility to express talents and interests without hiasan character value ornament wrapper.

Character value in local should be introduced and integrated for all study subjects including study subject of local history because by historical perspective it has the deepest study of local character. Application of historical values at college is proof of devotion to local genius from educational institution as end bridge for individual prior to arriving at dedication objective in the midst of communities who needs the person whose personality, his/her relation with another individual in the community to be imitated and followed. Wishfully, study subject of local history will not only result in the students or alumni who master living history solely, but also the human who has a perfect character from all character values implied for any historical event which has been studied.

\section{DISCUSSION}

\section{A. The Definition of Lempu}

In Indonesia language Lетрu' means honest as an opponent with bent. In some context, such word is synonym with sincere, true, fraudulent, lie, treasonous, Shyness, shabby, mayhem and others. It may be understood when finding the word of lempu' in locution of Bugis within lontara.

In Bugis language, any location for manifesting of honesty character; I make two as a fence, ie, nail polish, and jackfruit flower. Nail polish is pacci (paccing) and jackfruit flower 
lempu (lempu). In Lontara script, the word of pacci (paccing) either may be read as pacci and/or paccing. In this case, the later will be used which has to mean cleanliness. Lempu is honesty. Hence, the self fence of Bugis people is two those are clean and honest. It means that Bugis people maintain a selfimage as a clean and honest person. Another locution is "don't get other people right'. Similarly, paseng, previously, it is locution of 'dont' get wood if you had not falt down'.". Lempu or Lambusu has two important variants, those are matutu, it is to work accurately and carefully, for any step and action to be wise. The second variant is gellao gau-gau na, ie, good action in accordance with courtesy applied by the community or always doing any good action which will not violate community norms [1].

As to such honesty values expressed in locution of Iyaro lempue padai two monangnge ri tengnga dolangeng; ritenreki ponna, mompoo-i cappakna, ritenrek-i cappakna, mompoo- $i$ ponna. It means truth as bamboo over the ocean if its nucleus stressed then will emerge its end, and when its end stressed then will emerge its nucleus. In another word, surely, the true penny will present on the surface, he/she will not feel the loss forever. Truth and kindness will take sides it, trusted, his/her economy will revive and stable [2].

Presently, infrequently, the honesty will be found because some interests dominated by lust solely. Honesty is commitment according to the truth upheld based norms applied by the community [3]. In Makassar language, also it had been found some paseng on lambusuq (honest), for example, 1) antu lambusuka, natamangowa ri barang-barang iyamintu allaqbui umuruq (the honest person will not be greedy for goods prolonging life, 2) antu lambusuka, nibicarai ri tau ri bokona (the honest person will be chewed over by leaven generation, 3) antu lambusuka, anjari pareqna (business of the honest person will be success, 4) antu lambusuka, anjari anun-anu nikaddoq-kaddoqna siagang tau jaina (the honest person will produce foods successfully and people) [4].

Some messages from scholars of South Sulawesi revealed the meaning of lempu either by paseng or even by direct locution from the dialog with the king. Any sample of dialog between Kajao Laliddo and Arungpone.

Arungpone : what is a witness (insurance) of such honesty oh my grandma?

Kajao Laliqdong : Such exclamation, Arumpone.

Arungpone : what had been excavated, grandma?

Arungpone : the issues having been exclamation is, don't get crop is not yours. Don't get property being not yours and also not your heritage. Don't bring out buffalo from stall being not yours [5].

Pappaseng above reflecting any advice to offspring in order to act honestly, he/she will not be a long arm or even or to get another person right being not us because it will harm both parties. It has philosophy meaning for all persons especially for a leader who needs an advisor who has large insight and advances view. Such exclamation is a manifestation of honesty in order to practice truth and kindness for sake of community interests. Then, by practicing such exclamation, the life will be safe and peacefully.

There are eight issues as proof of honesty, those are: 1) to lift up the above, 2) to bring down the below, 3) to put forward the afore 4) to turn left the left 5) to turn right the right 6) to turn back the behind, 7) to let remain outside who stay outside; and 8) to let remain inside who stay inside.

Quoting of pappaseng above, it had given clarification that to do anything, it should be evaluated objectively, to place anything in accordance with its portion and to solve the problem fairly and wisely. So many people had promised easily, but, not all people may pay such promise. The person who had not paid the person he/she will get sanction such as lack of confidence from others to his/her self or even will be eliminated from community relationship.

The leader who always said humanely, trust to other humans, to think positively (correctly), to act kindly and be afraid to Allah SWT. Ideally, the leader should not be leaven by capability and honesty in order that any will had been given to his/her, to always commit kindly and accountable. Hence, the people having been chaired will feel convenient and confirmed at such country. Conversely, when the leader/ king always not talk honestly, the people will be misery and the country will be wrecked. Honesty is any main capital for everything interacted with the community, are those the rich or poor communities, all of them desire and claim to do honestly. Goodwill is any guidance for sailing through the ocean, life and bridging to the luck [6].

Said again Arung : there are four types of fragile wood (no strength), none of you please don't rest at one of those four types 1) fragile wood, rely on offspring 2) fragile wood, rely on intelligence 3) fragile wood, rely on richness 4) fragile wood, rely on bravery; as to such fragile wood, none of its positions is good, if it is on fire it will be burned thereby, if it is on air, the water will absorb thereto; if it is between fire and water then, it will be surrounded by rengat.

The meaning of such paseng doesn't rely on richness, intelligence, offspring and bravery solely, but, with full devotion based on noble common sense along with full submission to the greatest of almighty God who determines everything.

- As to king when he/she uphold honesty in judiciary then, 'land judicial' treated as an award.

- As to such water judicial is smart and accurate but it is not honesty, because the character of water always meanders, and its course to downward:

- As to king if he/she is respected and behave for selfsubmission to his/her. Usually, he/she will treat 'water judicial' as an award. If the king will soften, softened, to accelerate, he/she accelerates his/her award. So that, usually, the king open the way for axe, also for needle, if 
he/she is line (angry); also he/she open the way for needle, also for axe, if he/she is in condition of open-hearted and easy to forgive (as water character being always meandered);

- As to "in terms of wind" (judiciary according to wind character), to act hard and behave to dominate, not honesty, behaving according to his/her own, when he/she want from eastern, from western, from northern and from southern, what had emerged from heart it will be conducted. an; as to people when begin to behave so they no longer will subject to their king, no longer treat signal against their king, perfunctory to their king and his/her instruction, then, they will act as wind character, to realize judiciary as wind judicial, behave arbitrarily, to treat such judicial in accordance with predominance it has as such wind character demonstrating its power encountering all corners following its desire.

- As to judiciary according to fire character, behave turn on, burn tacitly; when people support such leader behavior or to provocate for further action, then, such leader treated judiciary same as fire character, as well as its behavior turn on and spread over corners.

- When people put a grudge to their leader then, such leader had made judiciary as fire turning on tacitly and unextinguishable.

- When such fire may not be extinguished then, it may result in badness, it will result in revenge one each other which may result in relationship destruction [7].

The meaning of paseng is in order that any king who adjudicate any case, he/she may refrain, to control with full equipoise. To elect very suitable judiciary with full honesty and no discrimination, reflect land symbolizing impartial intelligence. As to water, wind and fire character, all of those is same. To discuss judicature the law enforcer should reflect land in order that all award had been adjudicated reflects justice and humanity.

According to To Ciung (the smart person from Luwu), there are four principles of honesty as follows:

- When do wrong to forgive it immediately;

- If had been trusted, it will not be corrupted;

- $\quad$ Not greedy being not for self-own right

- It will not evaluate any kindness when his/her self-enjoy it; he/she may evaluate kindness when other people may feel such kindness [8]

\section{B. Lempu Value in Local History of South Sulawesi}

Elong ugi well known in terms of honesty and sanctity: the two made fences is honesty and sanctity. Honest is any right word in anybody self-own and anything will destroy honesty is words of a lie. Even there is other in terms of high expectation on honesty atmosphere taking place in community, wistfully, it will be lifelong, to stand firmly without vanquishing. Really, it indicates that Bugis community like honesty and wishfully, they stay in such atmosphere.

Sample from such issue above is when La Inca ascended the throne in Bone kingdom (1584-1595), frankly, he had been arrested to mingle other people wife, he had been warned but, he will kill the husband of such woman. Some princes and aristocratic of Bone had appeared to Arung Mamajang, Nenek La Inca'. Arung Matajang asks opinion of his nephew, Dammalaka. The people had demonstrated they're angry by burning center of Bone Kingdom. All of them had agreed that La Inca should descend the throne. Danmalaka had sent such decision to La Inca, unfortunately, Dammalaka had been killed then and there. Such grandma instructs to carry her and said: "I will kill with La Inca each other". The king who had not cared this honesty and sanctity values had been killed by his grandma while leaning back to palace staircase. And then, it is called La Inca Matinro'e ri Addenenna. Ciltural value and wisdom of alempureng especially, it had been revealed by paupau rikadong, among other thing it had said that when to maccana Luwu (smart person from Luwu), Tociung whose advice had been asked by candidate of Datu Soppeng, La Manussa Toakkarangeng, said that there are four lempu commitments those are: When do wrong to forgive it immediately; If had been trusted, it will not be corrupted; Not greedy being not for self-own right; It will not evaluate any kindness when his/her self-enjoy it; he/she may evaluate kindness when other people may feel such kindness.

Also had been revealed that La Pagala, grandma of Mallomo (1546-1654) who holds honest value and good presupposition very strongly then, he had adjudicated capital punishment for his son who had stolen wood for plowshare, and some years thereafter, it was not resulted by steal case he had been sentenced but his honesty to hide his commitment for some years.

Location of Mallomo's grandma in such honesty attitude had revealed the local wisdom of Sidenreng sounding; tradition will not recognize child and grandchild. Also in local wisdom locution had been revealed :

"I make two as fence, ie, nail polish and jackfruit flower. Nail polish is pacci (paccing) and jackfruit flower lempu (lempu). It means honesty and clean character being free from dirt and honesty is noble value to be owned [8].

Also, it had been found so many messages from alempureng Lontara. Karaeng Ujung Tanah in any message in terms of alempureng, sentencing: Don't be saturated with poverty, as strong as possible to enforce honesty values because honest person althought he/she will soak, then, he/she will emerge as well. In another place, he leaves a message that such honesty like bamboo float on water. You stress its end then will emerge its nucleus. Similarly, Karaeng Mathoaya had adviced Karaeng Pattingaloang with the message "fear the honest person". Arung Saotanre, Latoringeng To Taba had leaven message "indeed, initially, such honesty will be dominated by deception, but, finally, such honesty will determine as well". 
Don't let you lose intelligence and honesty, as to so-called intelligent is not difficult to practice it. So-called honest is good behave, good thought, correct thought, polite behavior and fear to God) [9].

And the traditional community in South Sulawesi who still maintain noble values culture to the present is a community of ammatoa Kajang located at regency of Bulukumba, \pm 150 to the southern of Makassar City. Such traditional community of Kajang had practiced honesty values in three dimensions, those are honest to Turiek Akrakna (One Almighty God), honest to inter-human and honest to self-own. The practice of honesty value to Turiek Akrakna is a manifestation of all His instructions and prohibitions truly. Whereas, the practice of honesty value to inter humans appreciate and respect other people right. And the practice of honesty value to self-own is enforcement of panggaukang lambusu (honest behave) principles. It means action based on truth in accordance with values and norms applied by the community. Those three practices of honesty values should be manifested by any community citizen either as leader of usual citizens.

The individual in the status of karaeng (leader) it will be recognized legitimately when he/she has honest treat. In locution of traditional community of Kajang had been said that lambusunuji nukaraeng (as result of your honesty then you will be karaeng or leader). A leader should always manifest honesty and proven by real commitment as locution of panggaukang lambusu (honest action commitment).

In community life of Kajang, the leader and people (public figure) will advise and warn each other (lingu sipakainga'). The manifestation of public figure advice to their leader as presented in locution of "Ikau karaengnga, lambusu bu'rungko, pa'lalangnganga angkuayaa" (you are leader, be honest as tree of bu'rungko straight up without branches and twigs). Individual who maintain honesty value in his/her life may be called dignified person properly. Dignified human is individual who always keep from sirik in his/her self. The human-like that always think, behave, talk and walk in accordance with values and norms in community. In the traditional community of Kajang, the human-like that called tau patantangnga pau mana (the person who hold tradition strongly) [10].

Those messages by those toacca contain very important moral aspect as reference for behaving either for up or bottom states. In big line, those messages contain suggestions and prohibitions as steps and motions of Bugis people who had not followed Islam religion comprising0: Ade', Rapang, Wari, and bicara. Upon arrival of Islam religion at Makassar, regulations contained in pangadereng most of them had not contradicted with Islam teaching, then, there was assimilation with pangadereng [11].

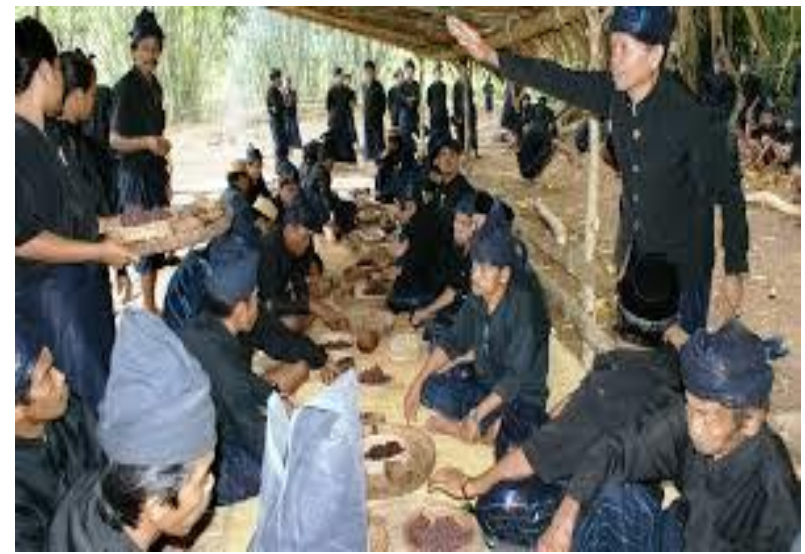

Fig 1. Community of Kajang Ammatoa

The values contained in the culture of such siri'na pacce among them: self-actualization, shame feeling and guilty feeling, loyalty and honesty. Self-actualization is the seriousness of individual to work maximally using potencies existing in his/her self. Shame and guilty feelings had been experienced by individual deeply because he/ she is not able to indicate cares to other human and will not be able to indicate discipline attitude for all activities.

Model from this loyalty is the capability to maintain trust having been given and to keep promise strongly. Honesty is synchronization between thought, heart said and action/ commitment hence, he/she may behave in accordance with inner hearth and truth. Whereas such self-corruption model is bribery, extortion, and nepotism. Bribery, civil servant who had taken a gift from another party in order that such civil servant gives more attention for interest of such giver. Extortion, the request for a gift to implement public duties. Nepotism, use of authority for appointment/assignment of closest person ass public officer without considering impact from such appointment/ assignment [12].

Any of traditional community still exist to the present in South Sulawesi is community of karampuang existing at Regency of Sinjai around $180 \mathrm{~km}$ from Makassar City. Noble values in this community are still maintained, one of them is honesty value. Traditional community of karampuang will be shock when they hear any officer had committed corruption or other abuse of power which should be model for community who had been lead. The leader of karampuang traditional community had not been waged, meanwhile, officer who had committed corruption has salary and another benefit. For honest leader then, it has bias to large public.

By historian of Bugis-Makassar Pangngaderreng had been viewed as the main concept of Bugis-Makassar culture, because it integrates the traditional wisdom of BugisMakassar people with values of Islam law. Also, such concept of siri' na pace culture had found its very astonished type. In manuscript of lontara', the meaning of siri' has two fundamental means "shy" (haya') dan "self-esteem" (ghirah). Meanwhile, pacce has meant the high social solidarity. In 
Islam tradition, such meaning is highly upheld, and even as important part of Muslim belief. The culture of siri' na pacce is inspiration resource and core from Islamic cultural building. Nevertheless, as if it is very absurd, when encounter the most current context having reflected some empirical realities no longer may maintain substance and meaning of siri na pacce.

Siri' na pacce no longer as a live precedent for the behavior of Bugis-Makassar community, in reality, religion and traditional values are individual cases and very significant experience for in religiosity and culture is very individual. Corruption phenomena supposed had dragged some BugisMakassar people who hold offices in this Indonesia Republic country (at center or in local; private or governmental sectors), entirely, it had not been released from a culture of siri' na pacce and Islamic doctrines which had been followed[13].

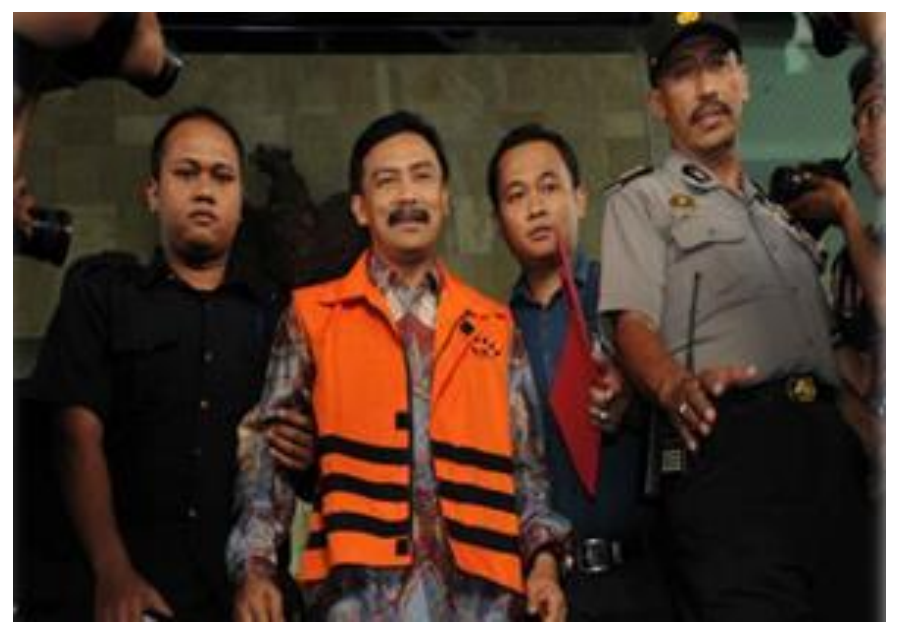

Fig 2. Andi Mallarangeng

Andi Mallarangeng as Secretary and member of the supervisory board and member of Upper Chamber of Democratic Party had been adjudicated 'guilty' in corruption criminal case of Hambalang structural and infrastructural development for the budget year of 2010-2012. Status of those two public figures as failure in transforming value thought or past teaching supposedly, it is the only romantic and had not been motivated to manifest an ideal concept for leadership (governmental) system. undeniably, this reality had occurred for almost community value system at South Sulawesi, including local wisdom on power and leadership.

\section{CONCLUSION}

Cutural value and wisdom of alempureng had been revealed at paopao rikadong, among them that when to maccana Luwu (intelligent person from Luwu), Tociung, whose advice had been asked by candidate of Datu Soppeng, La Manussa Toakkarangeng, said there are four lempu those are: When do wrong to forgive it immediately; If had been trusted, it will not be corrupted; Not greedy being not for selfown right; It will not evaluate any kindness when his/her selfenjoy it; he/she may evaluate kindness when other people may feel such kindness
The traditional community at South Sulawesi had preserved those noble values is community of ammota Kajang. Traditional community of Kajang had practiced honesty values by three dimensions, honest to Turiek Akrakna (One almighty god), honest to other human and honest to self-own.

\section{REFERENCE}

[1]. Darmapoetra, Juma. Suku Bugis Pewaris Keberanian Leluhur. Makassar: Arus Timur, 2014

[2]. Kamsinah, "Pemberdayaan Bahasa Dalam Pembentukan Karakter". Jurnal Arbiter FIB Universitas Andalas Padang, (2013) http://arbitrer.fib.unand.ac.id/index.php/arbitrer (diakses 5 Juni 2016).

[3]. Razak, Fitriani Sari Handayani. "Kuasa Wacana Kebudayaan Bugis Makassar Dalam Pilkada di Kabupaten Pinrang (Studi Kasus: Implementasi Nilai-Nilai Sipakatau, Sikainge' Dan Sipakalebbi Dalam Memobilisasi Massa Pada Pilkada Pinrang Tahun 2013”. Jurnal Politik Profetik UINAM Makassar Volume 5 Nomor 1 Tahun (2015) http://journal.uin-alauddin.ac.id/index.php/jpp (diakses 13 Juni 2016).

[4]. Iswary, Ery. Perempuan Makassar Relasi Gender Dalam Folklor. Yogyakarta: Ombak, 2010.

[5]. Rahim, Abdul \& Anwar Ibrahim. Nilai Demokrasi Dalam Budaya Bugis-Makassar. Makassar: Dinas Kebudayaan dan Pariwisata Propinsi Sulawesi Selatan, 2004.

[6]. Mustafa, Yahya. "Refleksi Kejujuran Masyarakat Bugis Dalam Pappasengna To Maccae Ri Luwu Sibawa Kajao Laliqdong Ri Bone". Jurnal Sawerigading Universitas Sawerigading: Makassar. Volume 20 No. 3 (2014).

[7]. Punangi, Abu Bakar, Abu Bakar. Pappaseng. Makassar: Badan Arsip dan Perpustakaan Wilayah Sulawesi Selatan Makassar, 1983.

[8]. Nonci. Sejarah Soppeng Zaman Prasejarah Sampai Kemerdekaan. Makassar: Aksara, 2003.

[9]. Yunus, Rahim. "Nilai-Nilai Islam Dalam Budaya Dan Kearifan Lokal (Konteks Budaya Bugis)". Jurnal Rihlah UIN Makassar Vol. II No. 1 Mei, (2015).

[10]. Faisal. "Nilai-Nilai Kepemimpinan Tradisional Dalam Komunitas Adat Kajang Di Sulawesi Selatan”, Jurnal Walasuji Balai Pelestarian Nilai Budaya Makassar Volume 6, No. 1 (2015) http://jurnalwalasuji.net/index.php/walasuji (diakses 20 Mei 2016).

[11]. Nurnaningsih. 2015. "Rekonstruksi Falsafah Bugis Dalam Pembinaan Karakter". Jurnal Lektur Keagamaan Deparemen Agama RI: Jakarta. Vol. 13, No. 2, (2015).

[12]. Rusdi, Mughny Ilman Wali \& Susanti Prasetyaningrum, "Nilai Budaya Siri'na Pacce Dan Perilaku Korupsi”. Jurnal Indigenous UM Malang Vol. 13, No. 2, 2015.

[13]. Noor, Nina Mariani (Editor). Etika dan Religiusitas Anti-Korupsi: Dari Konsep ke Praktek di Indonesia. Series editor: Christoph Stückelberger. Founder and Executive Director of Globethics.net and Professor of Ethics, University of Basel Globethics: Globethics.net Focus, 2015. 